\title{
Can reindeer husbandry management slow down the shrubification of the Arctic?
}

Megha Verma ${ }^{1,2}$

Henrike Schulte to Bühne ${ }^{2}$

Mailys Lopes ${ }^{2}$

Dorothee Ehrich ${ }^{3}$

Svetlana Sokovnina ${ }^{4}$

Stijn P. Hofhuis ${ }^{5}$

Nathalie Pettorelli2*

*Corresponding author. Email: Nathalie.Pettorelli@ioz.ac.uk, telephone: (+44) 02074496334

1: Department of Life Sciences, Imperial College London, Buckhurst Road, SL5 7PY Ascot, UK.

2: Institute of Zoology, Zoological Society of London, Regent's Park, NW1 4RY London, UK.

3: Department of Arctic and Marine Biology, UiT - The Arctic University of Troms $\varnothing, 9037$ Troms $\varnothing$, Norway.

4: Arctic research station, Institute of Plant and Animal Ecology Ural Branch Russian academy of Sciences, 629400, Zelenaya Gorka 21, Labytnangi, Yamal-Nenets Autonomous District, Russia.

5: Resource Ecology Group, Wageningen University, Droevendaalsesteeg 3a, 6708PB Wageningen, the Netherlands 


\begin{abstract}
Rapid climate change is threatening the stability and functioning of Arctic ecosystems. As the Arctic warms, shrubs have been widely observed to expand, which has potentially serious consequences for global climate regulation and for the ecological processes characterising these ecosystems. However, it is currently unclear why this shrubification has been spatially uneven across the Arctic, with herbivory being suggested as a key regulating factor. By taking advantage of freely available satellite imagery spanning three decades, we mapped changes in shrub cover in the Yamal Peninsula and related these to changes in summer temperature and reindeer population size. We found no evidence that shrubs had expanded in the study site, despite increasing summer temperatures. At the same time, herbivore pressure increased significantly, with the local reindeer population size growing by about $75 \%$. Altogether, our results thus point towards increases in large herbivore pressures having compensated for the warming of the Peninsula, halting the shrubification of the area. This suggests that strategic semi-domesticated reindeer husbandry, which is a common practice across the Eurasian Arctic, could represent an efficient environmental management strategy for maintaining open tundra landscapes in the face of rapid climate changes.
\end{abstract}

Keywords: satellite remote sensing, Arctic, tundra, shrubification, climate change, grazing, semidomesticated reindeer 


\section{Introduction}

2 Climate change is expected to accelerate in the $21^{\text {st }}$ century, creating unprecedented environmental challenges for human communities around the world while altering species ranges (Chen et al. 2011; Pinsky et al. 2013), rearranging species communities (Bertrand et al. 2011; Nooten et al. 2014; Dieleman et al. 2015; Liu et al. 2018) and changing ecosystem processes and functioning (Schuur et al. 2008; Durán et al. 2013; Roxy et al. 2016). This is especially true in the Arctic, where temperatures have increased at about twice the global average rate during recent decades (Bekryaev et al. 2010). These rapid and drastic changes in climatic conditions have led to many places in the Arctic showing increases in the distribution and vigour of woody vegetation. This so-called "shrubification" (MyersSmith et al. 2011) occurs as woody vegetation expands to new areas, fills gaps between existing patches, and/or grows taller. Shrubification is thought to be directly and indirectly controlled by climate change. Specifically, longer and warmer growing seasons (Blok et al. 2011), interactions between the timing of snow melt and nutrient cycling, and positive feedback loops of shrub cover on microclimate (Sturm et al. 2005; Wookey et al. 2009; Rixen et al. 2010) are all expected to promote increases in the distribution and vigour of woody vegetation. The shrubification of the Arctic can alter a large range of ecosystem processes and functions in tundras, including climate control and nutrient cycling (Myers-Smith et al. 2011). For instance, it can lead to decreased surface albedo (Strum et al. 2005) and faster snow melt in spring (Marsh, 2010), thereby potentially promoting the acceleration of global climate change. Shrub expansion can moreover be associated with an increase in passerine bird diversity (Ims \& Henden 2012), but also with a loss in plant species diversity, especially lichen, which may have direct consequences for consumers such as reindeer/caribous (Rangifer tarandus; Joly et al. 2009; Myers-Smith et al. 2011).

Shrubification of the Arctic is however not spatially uniform (Tape et al. 2012; Reichle et al. 2018), with some areas experiencing more rapid changes in the distribution and vigour of woody vegetation than others. These spatial differences have been attributed to various factors, including variation in soil disturbances from natural and anthropogenic causes (Myers-Smith et al. 2011). Herbivory by large ungulates is expected to be particularly important in shaping the response of shrubby vegetation to a changing climate, since herbivory directly reduces shrub cover, biomass and height (Christie et al. 2015). In experiments, grazing by semi-domesticated reindeers has been shown to counteract the effect of warming on shrub expansion (Post \& Pedersen 2008; Olofsson et al. 2009; Myers-Smith et al. 2011), suggesting that herbivory could be used as a management tool to mitigate the impacts of climate change on terrestrial Arctic ecosystems. Reindeer husbandry occurs over large parts of the Eurasian Arctic and is predominantly managed by indigenous peoples (Forbes et al. 2009). Large herbivore management is thus already part of socio-ecological systems in the Arctic and could 
therefore constitute a socially and culturally acceptable climate change mitigation strategy in the region (Bråthen et al. 2017). Literature assessing the extent to which large herbivores could reduce shrubification over large spatial and temporal scales (i.e. several 100 square kilometres and several decades) is yet currently sparse and limited to North America and Fennoscandia (Bernes et al. 2015; Bråthen et al. 2017). Few studies have focused on assessing these changes within specific regions in Russia. There is evidence that long-term (i.e. decades) grazing by herbivores reduces shrub cover and height more than short-term grazing (Kitti et al. 2009), but it is not clear whether and how these conclusions hold under rapid changes in climatic conditions.

To address this gap in knowledge, we used satellite remote sensing data to map changes in shrub cover spanning three decades across a relatively remote study site of about $400 \mathrm{~km}^{2}$ in southern Yamal, Russia. The Yamal Peninsula, which extends from the Arctic circle to the high Arctic, is recognised as a "hotspot of change", being exposed to rapid changes in environmental conditions (Walker et al. 2009, 2010). Other than rising temperatures, extensive grazing and trampling by reindeer herds indeed heavily influence the landscape (Forbes 1999; Walker et al. 2009), with the region being home to the world's largest population of semi-domesticated reindeer managed by the nomadic indigenous Nentsy (Forbes et al. 2009). Our objective was to assess the potential of intensive grazing by semi-domesticated reindeer to mitigate shrub cover expansion under increasing surface temperatures, to which end we compared trends of shrubification, long-term temperature change and herbivore population size.

\section{Material and methods}

\subsection{Study Area}

Our study area is in southern Yamal, Russia $\left(68.2^{\circ} \mathrm{N}, 69.1^{\circ} \mathrm{E}\right.$ ) and covers approximately $400 \mathrm{~km}^{2}$ (Figure 1). The mean daily temperature ranges from $-24.9^{\circ} \mathrm{C}$ in January to $14.45^{\circ} \mathrm{C}$ in July (World Meteorological Organisation 2019). The area has a constant snow cover from October until June and a yearly average precipitation of about $350 \mathrm{~mm}$ (Sokolov et al. 2012). The landscape has many rivers, streams and lakes; the lowlands are flooded in the spring (Ehrich et al. 2012; Sokolov et al. 2012). The study area's topography is predominantly flat but contains scattered hills (up to $40 \mathrm{~m}$ in height) and steep ridges along the waterbodies (Ehrich et al. 2012). The study site is situated the border of two main vegetation zones in the Yamal Peninsula: low-shrub tundra and erect dwarf shrub tundra (Walker et al. 2005). Low shrub communities are common on this site and are characteristically composed of a mixture of dwarf birch (Betula nana) and willow (Salix spp.) that are up to $50 \mathrm{~cm}$ high (Ehrich et al. 2012). Dense thickets of tall willows up to $2 \mathrm{~m}$ high are also found along water bodies (Pajunen et al. 
2010) and on fertile slopes. Plant cover is continuous across the study area (80-100\%) except for ridge crests (Sokolov et al. 2012).

\subsection{Temperature Data}

Arctic warming is known to occur at a rate of $1.36{ }^{\circ} \mathrm{C}$ per century (1875-2008), which is twice as fast as the Northern Hemisphere average $\left(0.79^{\circ} \mathrm{C}\right.$ per century; Bekryaev et al. 2010). To estimate the rate of warming in our study site, data on monthly air surface temperatures for the summer months between June - September (which corresponds to the growing season) at a resolution of $0.5^{\circ}$ (circa $55 \mathrm{~km}$ ) latitude/longitude grid cells from 1901 - 2018 were acquired from CRU TS4.03 (Harris et al. 2019). Since our study site overlapped two grid cells of this dataset, we first calculated the mean temperature between these two cells. For each year, we calculated the average summer season temperature as the mean of monthly temperatures from June to September. To test whether average summer temperatures changed over time, a linear model was fitted. Diagnostic plots indicated that a linear model was appropriate for the data.

\subsection{Reindeer Population Data}

No data on reindeer populations specifically for our study area was available. However, local reindeer densities are known to be relatively high compared to other parts of the Arctic, with grazing pressure having been found to be universally high throughout the Yamal Peninsula (Walker et al. 2009, 2010; Golovatin et al. 2012). We here assumed that overall trends in reindeer abundance were the same in our study area as in the rest of Yamal, and therefore estimated this trend in reindeer population size by collating abundance data for the whole Yamal Peninsula from three different studies: K. B. Klokov and S. A. Khrushchev (2004), M. G. Golovatin et al. (2012) and V. D. Bogdanov and M. G. Golovatin (2017). Temporal trends in abundance were assessed using the Mann-Kendall test.

\subsection{Shrub cover}

To capture long-term changes in shrub distribution, we mapped land cover using Landsat images for the years 1986, 1991, 1996, 2001, 2006 (all Landsat 4-5), 2011 (Landsat-7), 2016 and 2018 (Landsat8; all available for download at http://earthexplorer.usgs.gov). We used Landsat "Collection 1 Level 2" Surface Reflectance products (georeferenced, terrain-corrected and atmospherically corrected) processed on demand by the United States Geological Survey (USGS) as these are recognised as the most accurate pre-processed products (Young et al. 2017). The native cloud mask (CFMask) was used to identify and eliminate pixels that were covered by clouds in all scenes. To ensure that land cover classification was based on scenes from the peak-growing period, we acquired Landsat scenes 
close to the time of maximum greenness (Pettorelli 2013). To fill any gaps created by clouds, we created cloud free composite scenes for each year by selecting several overlapping satellite scenes that had been acquired close together in time. We histogram-matched these scenes to standardize the radiometric values before merging all overlapping scenes, resulting in cloud-free composite scenes.

Six land cover classes were discerned in the landscape, namely water bodies; sand; exposed ridges; shrub thickets (including willow thickets and closed canopy dwarf birch heath of $25 \mathrm{~cm}$ height or more, as well as mixed forms); wet lowlands; and mesic tundra (see Table S1 in Supplementary materials for a detailed description of these classes). Our supervised classifications were informed by a training dataset composed of the following elements: 1) very high resolution $(3 \mathrm{~m})$ imagery for the year 2011 (RapidEye imagery, $6^{\text {th }}$ August 2011), 2016 (4-Band Planet Scope, $2^{\text {nd }}$ September 2016) and 2018 (4Band Planet Scope, $13^{\text {th }}$ July 2016) of the entire study site; 2) ground-truthing points consisting of homogenous patches of more than $30 \times 30 \mathrm{~m}$ of the defined land cover types that were opportunistically sampled in July 2017 and georeferenced with hand-held GPS (these felt into 219 Landsat pixels); and 3) drone pictures (multispectral sensor (RGB), DJI Phantom 4, taken from a height of $80 \mathrm{~m}$ ) covering an area of ca 73 ha and containing willow thickets both on slopes and on flat areas. There was no available reference data to support a direct supervised classification of the scenes collected by Landsat in 1986, 1991, 1996, 2001, and 2006. To overcome this limitation, we opportunistically sampled pixels from the 2011 training dataset from areas identified as having stable land cover; these areas were identified using a spectral Change Vector Analysis (CVA, Schulte to Bühne et al. 2017). To maximise the amount of spectral information used in the CVA, we used Principal Components instead of bands or single indices as input for the CVA (Schulte to Bühne et al. 2017). We compared the change magnitude for each pixel to the median observed change magnitude across all pixels with the same land cover. We assumed that a pixel had undergone land cover change if its change magnitude was above the median change magnitude of its land cover. This threshold is conservative because an exceptional amount of change in surface reflectance needs to have occurred in the absence of land cover change to achieve this (Schulte to Bühne et al. 2017). This allowed us to build a training dataset to inform our supervised classification for the year 1986, 1991, 1996, 2001 and 2006 (Xian \& Homer 2010). We tested the validity of this approach by applying it to the years 2016 and 2018 and comparing the accuracy of the resulting map with those produced using independent validation data. The maps for the years 1986, 1991, 1996, 2001 and 2006 were all internally validated using the validation points created from the unchanged pixels. 
Supervised land cover classifications were performed using the Random Forest classifier in R (Liaw \& Wiener 2002), which generated 500 trees using three tuning levels; Random Forest has been demonstrated to perform robustly in different ecological settings (Belgiu \& Drăguţ 2016). Producer's and user's accuracies were calculated for all land cover maps. Producer's accuracy quantifies the probability that a given pixel will be assigned to the correct land cover class by the classification algorithm. By contrast, user's accuracy estimates the probability that the assigned class of a given pixel is correct. The area of each of the vegetation classes was calculated per year following the recommendations of Olofsson and colleagues (2013) and the trend over time was examined using a Mann-Kendall test.

\section{Results}

Average summer season temperatures (June - September) increased significantly between 1901 and $2018\left(F_{1,116}=5.72, p=0.02\right)$, with annual temperature increases of circa. $0.007^{\circ} \mathrm{C}$. This means that average summer season temperatures in 2018 were about $0.84^{\circ} \mathrm{C}$ warmer than in 1901 , and circa $0.229^{\circ} \mathrm{C}$ warmer than in 1986 (Figure 1). The semi-domesticated reindeer population on the Yamal Peninsula overall increased by about 75\% between 1986 and $2016(\tau=0.761, p<0.0001$; Figure 1$)$. Semi-domesticated reindeer abundance shows a drastic increase from 1986 to 2009, peaking at 327,073 individuals. An important increase in reindeer numbers in our study area was thus very likely.

Land cover was classified with suitable accuracy across all years, with overall accuracies ranging from approximately $82 \%$ to $91 \%$ (Table 1). Producer's and user's accuracies were relatively high in every vegetation class. Our approach to generating training data for the years 1986-2006 was unlikely to have inflated accuracy estimates (Table S2 in Supplementary materials). Shrub thickets showed high overall accuracies (83\% - 91\%). Using information derived from the above land cover classifications, we were unable to detect any significant change in the percentage cover of shrub thickets $(\tau=-0.50$, $p=0.11)$ or mesic tundra $(\tau=-0.143, p=0.71$; Figure 2$)$.

\section{Discussion}

Natural vegetation distribution is both a consequence and a driver of global environmental change (Foley et al. 2005; Franklin et al. 2016; Song et al. 2018). Understanding changes in vegetation cover can help provide insight into ecosystem response to environmental change, and consequently support effective ecosystem management strategies (Walther et al. 2002; Foley et al. 2005). With limited longterm data on vegetation distribution available for the Arctic, it is however difficult to make inferences 
about the past and understand the combined effects of climate change and herbivory on tundra landscapes. Using Landsat satellite imagery over the 1986-2018 period, this study demonstrates how significant increases in temperature and grazing pressures did not result in the expected change in shrub cover in the Yamal Peninsula, suggesting that growing semi-domesticated reindeer numbers may have counteracted the effects of rising temperatures (Figure 1) on shrub growth in the region (Figure 2). These results are important as they point toward large herbivore management as being a potentially efficient management strategy for maintaining open arctic landscapes in times of rapid climatic changes.

In contrast to the widely accepted phenomenon of "shrubification" associated with warming and documented in previous remote sensing studies (Beck \& Goetz 2011; Myers-Smith et al. 2011; Naito \& Cairns 2011), our results highlight a lack of change in shrub cover in our study system over the past 30 years (Figure 2). These results echo previous findings, including those by two long-term plot-based studies in south Greenland (Damgaard et al. 2016) and north-eastern Alaska (Jorgenson et al. 2015), which similarly reported no trend in shrub cover despite the warming of the areas. Several reasons may explain such an outcome. First, this could be a result of the relatively modest increase in summer temperatures for the region (see Figure 1). Second, the lack of reported trend could be due to differences in responses of shrub species to climate change coupled with our inability to differentiate tall shrubs from dwarf shrubs from space. Long-term warming experiments have indeed reported that tall shrubs (e.g. Salix spp) increase their distribution with rising temperature, while dwarf shrubs (e.g. Betula nana) tend to respond in the opposite way (Elmendorf et al. 2012b). It is possible that taller shrub species have increased over the study period, while dwarf shrub species have decreased, something we would have been unable to detect given our methodological approach. Third, it could be speculated that although overall shrub cover showed no significant change, shrub height and even below-ground biomass have been responding positively to warming conditions (Myers-Smith et al. 2011), something we would have not been able to detect using Landsat imagery.

However, a likely hypothesis for explaining our results is that changes in herbivory pressure compensated for the impacts of climate change on shrub cover (Olofsson et al. 2009). Given the significant increase in reindeer population observed in the Yamal Peninsula over the period considered (Figure 1), one would indeed predict shrub cover to decrease with increased herbivore abundance as a result of increased grazing and trampling (Hilker et al. 2014); however, our results do not suggest such a response. Again, different mechanisms could explain the observed patterns, the simplest one being that reindeer grazing controlled shrub expansion through indiscriminate grazing. Bråthen et al. (2017) and Ravolainen et al. (2011) both found evidence that at high densities, reindeers can prevent shrubification by keeping the small stages of shrubs such as saplings in a "browse trap" independent 
of increases in surface temperatures. However, another possibility is that reindeer grazing led to a change in shrub species composition without any impact on distribution. Previous studies on reindeer grazing behaviours indeed found that these large herbivores prefer willows (Salix spp.) over birch (Betula spp.), due to the difference in anti-browsing defensive compounds found in the species (Christie et al. 2015). As the shrub thicket land cover classification pooled both shrub species together, the dissimilar influence of herbivory on the vegetation could have been overlooked. At present, it is, however, difficult to isolate the impact of herbivory from the impacts of climate change on vegetation distribution as reindeer husbandries in Yamal largely follow a nomadic lifestyle where migration is determined by both ecological and cultural considerations (Degteva \& Nellemann 2013). Because of this, there are no distinct areas in Yamal where reindeers have been clearly excluded (Walker et al. 2009).

Admittedly, there are several limitations associated with our study. While this research focused on the combined impacts of summer temperatures and reindeer herbivory on shrub cover on the Yamal Peninsula, other variables might be important for understanding the observed lack of vegetation changes in the area. For instance, a study in Alaska found that precipitation, especially snow, boosted shrub expansion by providing a microclimate that insulated vegetation from extreme winter temperatures (Wahren et al. 2005). In addition, the inclusion of herbivory pressures from small herbivores such as voles and lemmings (Olofsson et al. 2014) could help elucidate plant-herbivore interaction in the region. However, literature suggests that, compared to other regions in the Arctic such as Fennoscandia, small rodent abundance has been relatively low at our study site for the last 20 years (Fufachev et al. 2019). The use of multispectral optical satellite imagery to map the dynamics of tundra vegetation moreover limited the scope of our investigation. For example, the consideration of the Landsat archives enabled us to provide a satisfactory temporal perspective on changes in vegetation classes but limited our ability to explore fine scale changes in shrub distribution. As previously acknowledged, changes in shrub species distribution and vertical growth could not be detected using Landsat imagery.

\section{Conclusions}

232

Climate models predict that $2-10{ }^{\circ} \mathrm{C}$ increases in Arctic temperature could transform more than half of the tundra surface into shrublands before the next century (Pearson et al. 2013); such changes in shrub cover could have dramatic implications for ecosystem functioning and people while leading to positive feedbacks with warming (Wookey et al. 2009; Myers-Smith et al. 2011). Here, it is likely that 
observational evidence that semi-domesticated reindeer management within a sustainable range (which will likely vary between sites based on vegetation and regional climate characteristics) could be a plausible strategy for maintaining and protecting tundra landscapes from transformation in the face of rapid climate changes. This study also provides further evidence that shrubification is not ubiquitous across the Arctic and emphasises the importance of long-term ecological monitoring for informing site-specific environmental management policies.

\section{Acknowledgements}

We would like to thank Aleksandr and Natalia Sokolov for welcoming us to work in their long-term study area.

\section{Funding}

This study considered ground-based information collected by the "Yamal EcoSystem" project (362259) from the Terrestrial Flagship of the High North Research Centre for Climate and the Environment (Fram Centre). This research was also made possible thanks to the financial support of the Russian Foundation for Basic Research (grant № 18-05-60261)

\section{References}

Beck, P. S., \& Goetz, S. J. (2011). Satellite observations of high northern latitude vegetation productivity changes between 1982 and 2008: ecological variability and regional differences. Environmental Research Letters, 6(4), 045501. https://doi.org/10.1088/17489326/7/2/029501

Bekryaev, R. V., Polyakov, I. V., \& Alexeev, V. A. (2010). Role of polar amplification in long-term surface air temperature variations and modern Arctic warming. Journal of Climate, 23(14), 3888-3906. https://doi.org/10.1175/2010JCLI3297.1

Belgiu, M., \& Drăguţ, L. (2016). Random forest in remote sensing: A review of applications and future directions. ISPRS Journal of Photogrammetry and Remote Sensing, 114, 24-31. https://doi.org/10.1016/j.isprsiprs.2016.01.011

Bertrand, R., Lenoir, J., Piedallu, C., Riofrío-Dillon, G., de Ruffray, P., Vidal, C., Pierrat, J., \& Gégout, J. C. (2011). Changes in plant community composition lag behind climate warming in lowland forests. Nature, 479(7374), 517. https://doi.org/10.1038/nature10548

Bernes, C., Jonsson, B. G., Junninen, K., Lõhmus, A., Macdonald, E., Müller, J., \& Sandström, J. (2015). What is the impact of active management on biodiversity in boreal and temperate forests set aside for conservation or restoration? A systematic map. Environmental Evidence, 4(1), 25. https://doi.org/10.1186/s13750-015-0050-7

Blok, D., Schaepman-Strub, G., Bartholomeus, H., Heijmans, M. M., Maximov, T. C., \& Berendse, F. (2011). The response of Arctic vegetation to the summer climate: relation between shrub cover, NDVI, surface albedo and temperature. Environmental Research Letters, 6(3), 035502. https://doi.org/10.1088/1748-9326/6/3/035502

Bogdanov, V. D., \& Golovatin, M. G. (2017). Anthrax in Yamal: An ecological view on traditional reindeer husbandry. Russian Journal of Ecology, 48(2), 95-100. https://doi.org/10.1134/S1067413617020059 
Bråthen, K. A., Ravolainen, V. T., Stien, A., Tveraa, T., \& Ims, R. A. (2017). Rangifer management controls a climate-sensitive tundra state transition. Ecological applications, 27(8), 24162427. https://doi.org/10.1002/eap.1618

Chen, I. C., Hill, J. K., Ohlemüller, R., Roy, D. B., \& Thomas, C. D. (2011). Rapid range shifts of species associated with high levels of climate warming. Science, 333(6045), 1024-1026. https://doi.org/10.1126/science.1206432

Christie, K. S., Bryant, J. P., Gough, L., Ravolainen, V. T., Ruess, R. W., \& Tape, K. D. (2015). The role of vertebrate herbivores in regulating shrub expansion in the Arctic: a synthesis. BioScience, 65(12), 1123-1133. https://doi.org/10.1093/biosci/biv137

Damgaard, C., Raundrup, K., Aastrup, P., Langen, P. L., Feilberg, J., \& Nabe-Nielsen, J. (2016). Arctic resilience: no evidence of vegetation change in response to grazing and climate changes in South Greenland. Arctic, Antarctic, and Alpine Research, 48(3), 531-549. https://doi.org/10.1657/AAAR0016-005

Degteva, A., \& Nellemann, C. (2013). Nenets migration in the landscape: impacts of industrial development in Yamal peninsula, Russia. Pastoralism: Research, Policy and Practice, 3(1), 15. https://doi.org/10.1186/2041-7136-3-15

Dieleman, C. M., Branfireun, B. A., McLaughlin, J. W., \& Lindo, Z. (2015). Climate change drives a shift in peatland ecosystem plant community: implications for ecosystem function and stability. Global change biology, 21(1), 388-395. https://doi.org/10.1111/gcb.12643

Durán, A. P., Casalegno, S., Marquet, P. A., \& Gaston, K. J. (2013). Representation of ecosystem services by terrestrial protected areas: Chile as a case study. PLoS one, 8(12), e82643. https://doi.org/10.1371/journal.pone.0082643

Ehrich, D., Henden, J. A., Ims, R. A., Doronina, L. O., Killengren, S. T., Lecomte, N., Pokrovsky, I. G., Skogstad, G., Sokolov, A. A., Yoccoz, N. G., \& Yoccoz, N. G. (2012). The importance of willow thickets for ptarmigan and hares in shrub tundra: the more the better?. Oecologia, 168(1), 141-151. https://doi.org/10.1007/s00442-011-2059-0

Elmendorf, S. C., Henry, G. H., Hollister, R. D., Björk, R. G., Boulanger-Lapointe, N., Cooper, E. J., ... \& Gill, M. (2012). Plot-scale evidence of tundra vegetation change and links to recent summer warming. Nature Climate Change, 2(6), 453. https://doi.org/10.1038/nclimate1465

Foley, J. A., DeFries, R., Asner, G. P., Barford, C., Bonan, G., Carpenter, S. R., ... \& Helkowski, J. H. (2005). Global consequences of land use. science, 309(5734), 570-574. https://doi.org/10.1126/science.1111772

Forbes, B. C. (1999). Land use and climate change on the Yamal Peninsula of north-west Siberia: some ecological and socio-economic implications. Polar Research, 18(2), 367-373. https://doi.org/10.3402/polar.v18i2.6597

Forbes, B. C., Stammler, F., Kumpula, T., Meschtyb, N., Pajunen, A., \& Kaarlejärvi, E. (2009). High resilience in the Yamal-Nenets social-ecological system, West Siberian Arctic, Russia. Proceedings of the National Academy of Sciences, 106(52), 22041-22048. https://doi.org/10.1073/pnas.0908286106

Franklin, J., Serra-Diaz, J. M., Syphard, A. D., \& Regan, H. M. (2016). Global change and terrestrial plant community dynamics. Proceedings of the National Academy of Sciences, 113(14), 37253734. https://doi.org/10.1073/pnas.1519911113

Fufachev, I. A., Ehrich, D., Sokolova, N. A., Sokolov, V. A., \& Sokolov, A. A. (2019). Flexibility in a changing arctic food web: can rough-legged buzzards cope with changing small rodent communities?. Global change biology. https://doi.org/10.1111/gcb.14790

Golovatin, M. G., Morozova, L. M., \& Ektova, S. N. (2012). Effect of reindeer overgrazing on vegetation and animals of tundra ecosystems of the Yamal peninsula. Czech Polar Reports, 2(2), 80-91. https://doi.org/10.5817/CPR2012-2-8

Harris, I. P. D. J. (2019). Release notes for CRU TS v4.03. Retrieved on 30 March 2020 [Online] https://crudata.uea.ac.uk/cru/data/hrg/cru ts 4.03/Release Notes CRU TS4.03.txt. Dataset DOI: http://dx.doi.org/10.5285/d6768285fdc8408bbb9b02bb0f317774 
Hilker, T., Natsagdorj, E., Waring, R. H., Lyapustin, A., \& Wang, Y. (2014). Satellite observed widespread decline in Mongolian grasslands largely due to overgrazing. Global Change Biology, 20(2), 418-428. https://doi.org/10.1111/gcb.12365

Ims, R. A., \& Henden, J. A. (2012). Collapse of an arctic bird community resulting from ungulateinduced loss of erect shrubs. Biological conservation, 149(1), 2-5. https://doi.org/10.1016/j.biocon.2012.02.008

Joly, K., Jandt, R. R., \& Klein, D. R. (2009). Decrease of lichens in Arctic ecosystems: the role of wildfire, caribou, reindeer, competition and climate in north-western Alaska. Polar Research, 28(3), 433-442. https://doi.org/10.1111/j.1751-8369.2009.00113.x

Jorgenson, J. C., Raynolds, M. K., Reynolds, J. H., \& Benson, A. M. (2015). Twenty-five year record of changes in plant cover on tundra of northeastern Alaska. Arctic, Antarctic, and Alpine Research, 47(4), 785-806. https://doi.org/10.1657/AAAR0014-097

Kitti, H., Forbes, B. C., \& Oksanen, J. (2009). Long-and short-term effects of reindeer grazing on tundra wetland vegetation. Polar Biology, 32(2), 253-261. https://doi.org/10.1007/s00300$\underline{008-0526-9}$

Klokov, K. B., \& Khrushchev, S. A. (2004) Reideer Husbandry by the Indigenous Peoples of the Russian North: an Analytical Review. St. Petersburg: VVM

Liaw, A., \& Wiener, M. (2002). Classification and regression by randomForest. $R$ news, 2(3), 18-22.

Liu, D., Peñuelas, J., Ogaya, R., Estiarte, M., Tielbörger, K., Slowik, F., Yang, X., \& Bilton, M. C. (2018). Species selection under long-term experimental warming and drought explained by climatic distributions. New Phytologist, 217(4), 1494-1506. https://doi.org/10.1111/nph.14925

Marsh, P., Bartlett, P., MacKay, M., Pohl, S., \& Lantz, T. (2010). Snowmelt energetics at a shrub tundra site in the western Canadian Arctic. Hydrological Processes, 24(25), 3603-3620. https://doi.org/10.1002/hyp.7786

Myers-Smith, I. H., Forbes, B. C., Wilmking, M., Hallinger, M., Lantz, T., Blok, D., Tape, K. D., MaciasFauria, M., Sass-Klaassen, U., Lévesque, E. (2011). Shrub expansion in tundra ecosystems: dynamics, impacts and research priorities. Environmental Research Letters, 6(4), 045509. https://doi.org/ 10.1088/1748-9326/6/4/045509

Naito, A. T., \& Cairns, D. M. (2011). Patterns and processes of global shrub expansion. Progress in Physical Geography, 35(4), 423-442. https://doi.org/10.1177/0309133311403538

Nooten, S. S., Andrew, N. R., \& Hughes, L. (2014). Potential impacts of climate change on insect communities: a transplant experiment. PLoS One, 9(1), e85987. https://doi.org/10.1371/journal.pone.0085987

Olofsson, J., Oksanen, L., Callaghan, T., Hulme, P. E., Oksanen, T., \& Suominen, O. (2009). Herbivores inhibit climate-driven shrub expansion on the tundra. Global Change Biology, 15(11), 26812693. https://doi.org/10.1111/i.1365-2486.2009.01935.x

Olofsson, P., Foody, G. M., Stehman, S. V., \& Woodcock, C. E. (2013). Making better use of accuracy data in land change studies: Estimating accuracy and area and quantifying uncertainty using stratified estimation. Remote Sensing of Environment, 129, 122-131. https://doi.org/10.1016/j.rse.2012.10.031

Olofsson, J., Oksanen, L., Oksanen, T., Tuomi, M., Hoset, K. S., Virtanen, R., \& Kyrö, K. (2014). Longterm experiments reveal strong interactions between lemmings and plants in the Fennoscandian highland tundra. Ecosystems, 17(4), 606-615. https://doi.org/10.1007/s10021-013-9740-6

Pajunen, A. M., Kaarlejärvi, E. M., Forbes, B. C., \& Virtanen, R. (2010). Compositional differentiation, vegetation-environment relationships and classification of willow-characterised vegetation in the western Eurasian Arctic. Journal of Vegetation Science, 21(1), 107-119. https://doi.org/10.1111/i.1654-1103.2009.01123.x

Pearson, R. G., Phillips, S. J., Loranty, M. M., Beck, P. S., Damoulas, T., Knight, S. J., \& Goetz, S. J. (2013). Shifts in Arctic vegetation and associated feedbacks under climate change. Nature Climate Change, 3(7), 673. https://doi.org/10.1038/nclimate1858 
Pettorelli, N. (2013). The normalized difference vegetation index. Oxford University Press.

Pinsky, M. L., Worm, B., Fogarty, M. J., Sarmiento, J. L., \& Levin, S. A. (2013). Marine taxa track local climate velocities. Science, 341(6151), 1239-1242. https://doi.org/10.1126/science.123935

Post, E., \& Pedersen, C. (2008). Opposing plant community responses to warming with and without herbivores. Proceedings of the National Academy of Sciences, 105(34), 12353-12358. https://doi.org/10.1073/pnas.0802421105

Ravolainen, V. T., Bråthen, K. A., Ims, R. A., Yoccoz, N. G., Henden, J. A., \& Killengreen, S. T. (2011). Rapid, landscape scale responses in riparian tundra vegetation to exclusion of small and large mammalian herbivores. Basic and Applied Ecology, 12(8), 643-653. https://doi.org/10.1016/j.baae.2011.09.009

Reichle, L. M., Epstein, H. E., Bhatt, U. S., Raynolds, M. K., \& Walker, D. A. (2018). Spatial heterogeneity of the temporal dynamics of arctic tundra vegetation. Geophysical Research Letters, 45(17), 9206-9215. https://doi.org/10.1029/2018GL078820

Rixen, C., Schwoerer, C., \& Wipf, S. (2010). Winter climate change at different temporal scales in Vaccinium myrtillus, an Arctic and alpine dwarf shrub. Polar Research, 29(1), 85-94. https://doi.org/10.1111/j.1751-8369.2010.00155.x

Roxy, M. K., Modi, A., Murtugudde, R., Valsala, V., Panickal, S., Prasanna Kumar, S., ... \& Lévy, M. (2016). A reduction in marine primary productivity driven by rapid warming over the tropical Indian Ocean. Geophysical Research Letters, 43(2), 826-833. https://doi.org/10.1002/2015GL066979

Schulte to Bühne, H., Wegmann, M., Durant, S. M., Ransom, C., de Ornellas, P., Grange, S., \& Pettorelli, N. (2017). Protection status and national socio-economic context shape land conversion in and around a key transboundary protected area complex in West Africa. Remote Sensing in Ecology and Conservation, 3(4), 190-201. https://doi.org/10.1002/rse2.47

Schuur, E. A., Bockheim, J., Canadell, J. G., Euskirchen, E., Field, C. B., Goryachkin, S. V., ... \& Mazhitova, G. (2008). Vulnerability of permafrost carbon to climate change: Implications for the global carbon cycle. BioScience, 58(8), 701-714. https://doi.org/10.1641/B580807

Sokolov, V., Ehrich, D., Yoccoz, N. G., Sokolov, A., \& Lecomte, N. (2012). Bird communities of the Arctic shrub tundra of Yamal: habitat specialists and generalists. PLoS One, 7(12), e50335. https://doi.org/10.1371/journal.pone.0050335

Song, X. P., Hansen, M. C., Stehman, S. V., Potapov, P. V., Tyukavina, A., Vermote, E. F., \& Townshend, J. R. (2018). Global land change from 1982 to 2016. Nature, 560(7720), 639. https://doi.org/10.1038/s41586-018-0411-9

Sturm, M., Douglas, T., Racine, C., \& Liston, G. E. (2005). Changing snow and shrub conditions affect albedo with global implications. Journal of Geophysical Research: Biogeosciences, 110(G1). https://doi.org/10.1029/2005JG000013

Tape, K. D., Hallinger, M., Welker, J. M., \& Ruess, R. W. (2012). Landscape heterogeneity of shrub expansion in Arctic Alaska. Ecosystems, 15(5), 711-724. https://doi.org/10.1007/s10021012-9540-4

Walker, D. A., Raynolds, M. K., Daniëls, F. J., Einarsson, E., Elvebakk, A., Gould, W. A., ... \& Moskalenko, N. G. (2005). The circumpolar Arctic vegetation map. Journal of Vegetation Science, 16(3), 267-282. https://doi.org/10.1111/j.1654-1103.2005.tb02365.x

Walker, D. A., Leibman, M. O., Epstein, H. E., Forbes, B. C., Bhatt, U. S., Raynolds, M. K., ... \& Kaarlejärvi, E. (2009). Spatial and temporal patterns of greenness on the Yamal Peninsula, Russia: interactions of ecological and social factors affecting the Arctic normalized difference vegetation index. Environmental Research Letters, 4(4), 045004. https://doi.org/10.1088/1748-9326/4/4/045004

Walker, D. A., Forbes, B. C., Leibman, M. O., Epstein, H. E., Bhatt, U. S., Comiso, J. C., Drozdov, D. S., Gubarkov, A. A., Jia, G. J., Kaarlejärvi, E. (2010). Cumulative effects of rapid land-cover and 
land-use changes on the Yamal Peninsula, Russia. In Eurasian Arctic land cover and land use in a changing climate. Springer, Dordrecht.

Walther, G. R., Post, E., Convey, P., Menzel, A., Parmesan, C., Beebee, T. J., \& Bairlein, F. (2002). Ecological responses to recent climate change. Nature, 416(6879), 389. https://doi.org/10.1038/416389a

Wahren, C. H., Walker, M. D., \& Bret-Harte, M. S. (2005). Vegetation responses in Alaskan arctic tundra after 8 years of a summer warming and winter snow manipulation experiment. Global Change Biology, 11(4), 537-552. https://doi.org/10.1111/j.13652486.2005.00927.x

World Meterological Organisation. (2019). World Meterological Organisation. Available from http://worldweather.wmo.int/en/home.html (accessed 26 July 2019).

394

Wookey, P. A., Aerts, R., Bardgett, R. D., Baptist, F., Bråthen, K. A., Cornelissen, J. H., ... \& Shaver, G. R. (2009). Ecosystem feedbacks and cascade processes: understanding their role in the responses of Arctic and alpine ecosystems to environmental change. Global Change Biology, 15(5), 1153-1172. https://doi.org/10.1111/j.1365-2486.2008.01801.x

Xian, G., \& Homer, C. (2010). Updating the 2001 National Land Cover Database impervious surface products to 2006 using Landsat imagery change detection methods. Remote Sensing of Environment, 114(8), 1676-1686. https://doi.org/10.1016/j.rse.2010.02.018

Young, N. E., Anderson, R. S., Chignell, S. M., Vorster, A. G., Lawrence, R., \& Evangelista, P. H. (2017). A survival guide to Landsat preprocessing. Ecology, 98(4), 920-932. https://doi.org/10.1002/ecy.1730 
404

405 Table 1: Area-adjusted user and producer accuracies for shrub thickets, as well as overall area406 adjusted accuracy of the land cover maps generated for the years 1986-2018. Confidence intervals at $40795 \%$ confidence levels given in brackets were calculated based on the methodology proposed by 408 Olofsson et al. (2013). Producer's accuracy quantifies the probability that a given pixel will be assigned 409 to the correct land cover class by the classification algorithm. By contrast, user's accuracy estimates 410 the probability that the assigned class of a given pixel is correct. Overall accuracy corresponds to the percentage of correctly identified pixels across the entire study site.

412

\begin{tabular}{cccc}
\hline \multirow{2}{*}{ Year } & \multicolumn{2}{c}{ Shrub Thickets } & \\
\cline { 2 - 3 } & $\begin{array}{c}\text { User's Accuracy } \\
(\%)\end{array}$ & $\begin{array}{c}\text { Producer's Accuracy } \\
(\%)\end{array}$ & Overall Accuracy (\%) \\
\hline 1986 & $86.7( \pm 4.6)$ & $65.4( \pm 7.8)$ & $83.9( \pm 2.5)$ \\
1991 & $94.4( \pm 2.9)$ & $55.3( \pm 7.8)$ & $87.2( \pm 2.5)$ \\
1996 & $94.5( \pm 2.9)$ & $77.7( \pm 7.1)$ & $86.9( \pm 2.2)$ \\
2001 & $94.4( \pm 3.4)$ & $86.1( \pm 8.1)$ & $85.7( \pm 2.6)$ \\
2006 & $97.0( \pm 2.3)$ & $78.0( \pm 8.0)$ & $91.4( \pm 1.9)$ \\
2011 & $94.6( \pm 2.3)$ & $97.3( \pm 3.0)$ & $89.9( \pm 1.8)$ \\
2016 & $94.1( \pm 5.0)$ & $70.9( \pm 15.7)$ & $84.1( \pm 4.3)$ \\
2018 & $91.9( \pm 4.1)$ & $84.9( \pm 7.4)$ & $88.1( \pm 2.1)$ \\
\hline
\end{tabular}

413 
A
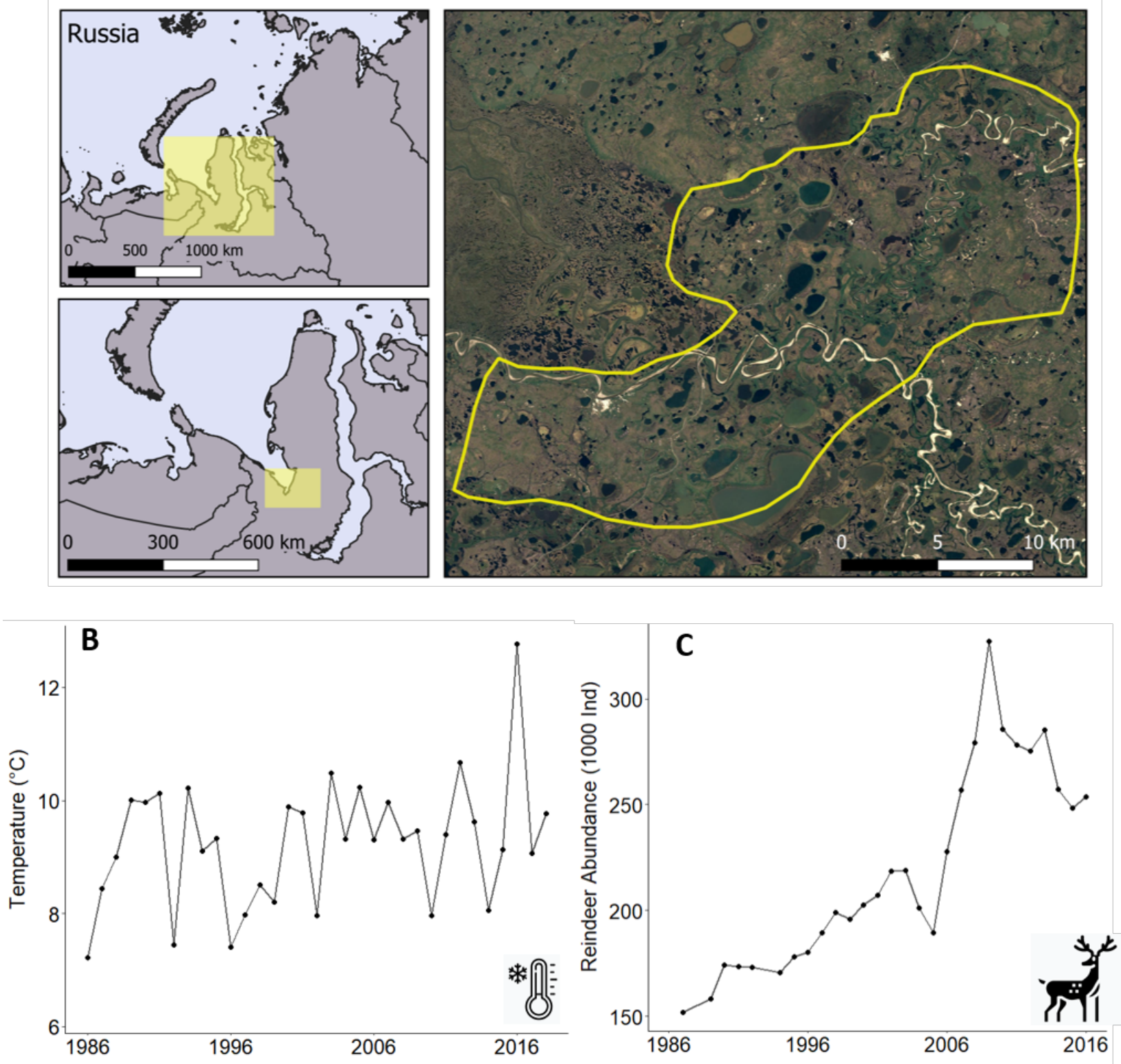

Figure 1. (A) Overview of the study site located in Southern Yamal Peninsula, Russia. The two small insets show the position of our study site within Russia and then the Yamal Peninsula (yellow square). The larger inset shows the boundary of our study site in yellow outlined over the base scene from Google Earth Engine, which has a spatial resolution of $3 \mathrm{~m}$. (B) Average monthly summer temperature for the months June - September from 1986 to 2018. The data was acquired from CRU TS3.10 (Harris et al. 2019). (C) Semi-domesticated reindeer abundance (1000 individuals) per year for the period 1986 - 2016 for the entire Yamal Peninsula region collated from three different studies (and averaged in the case of disagreement): Klokov and Khrushchev (2004); Golovatin et al. (2012); and Bogdanov and Golovatin (2017). 


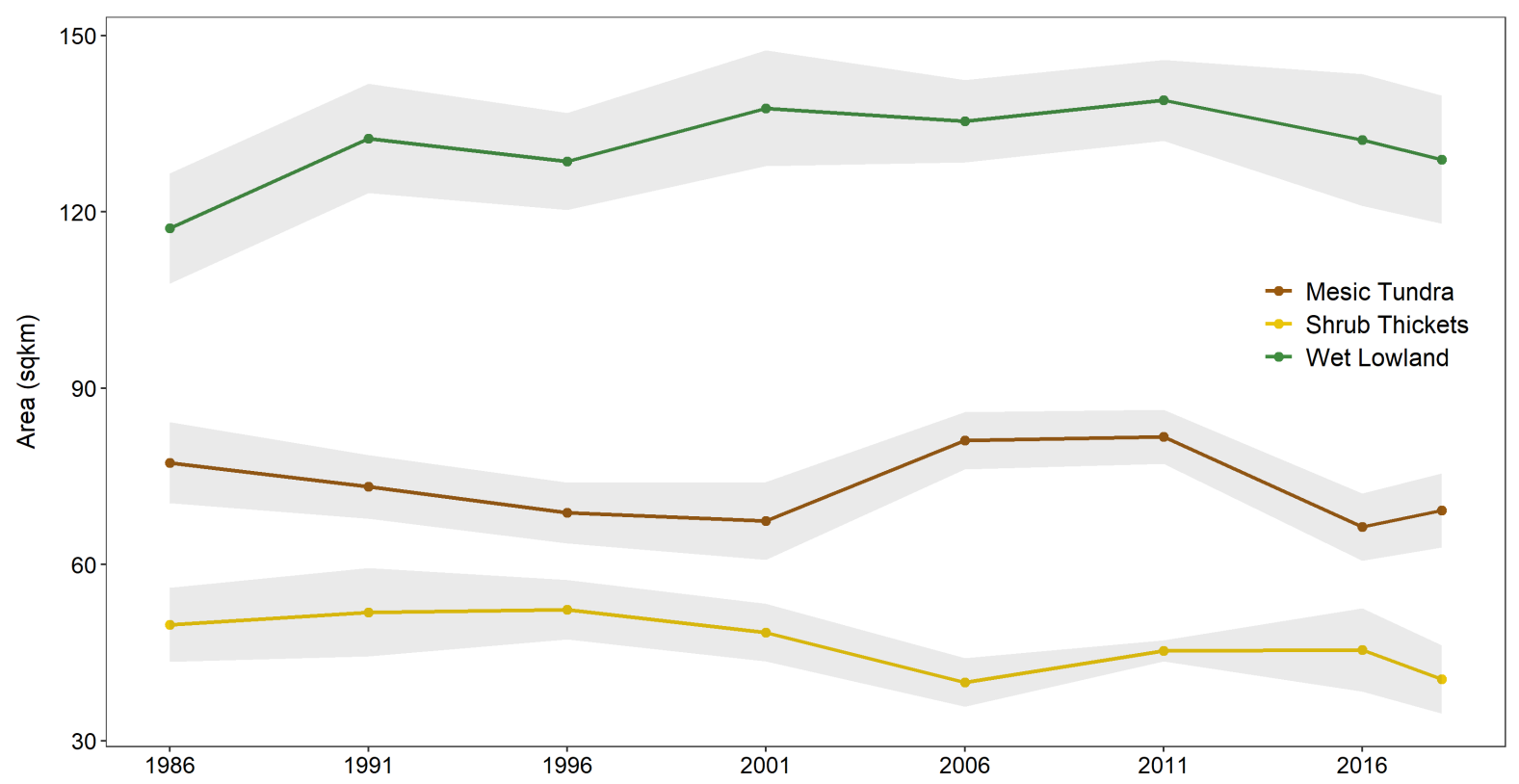

429 Figure 2. Cover of the different vegetation classes at the study site from 1986 to 2018, based on land 430 cover classifications from 1986 to 2016. The shaded areas indicate the margin of error with a 95\% 431 confidence interval (calculated based on the methodology suggested by Olofsson et al. 2013). 
Table S1. Description of land cover classes used in this study.

\begin{tabular}{|c|c|c|}
\hline Type & Class & Description \\
\hline \multirow{3}{*}{$\begin{array}{l}\text { Non- } \\
\text { Vegetation }\end{array}$} & Water Bodies & River and Lakes \\
\hline & Sand & $\begin{array}{l}\text { Loose sand and gravel found close to riverbanks and } \\
\text { exposed hills. }\end{array}$ \\
\hline & $\begin{array}{l}\text { Exposed } \\
\text { Ridges }\end{array}$ & $\begin{array}{l}\text { Limited plant cover with more than } 25 \% \text { of the area } \\
\text { covered by biological soil crust. Vegetation composed } \\
\text { of graminoids, lichens and prostrate dwarf shrubs less } \\
\text { than } 5 \mathrm{~cm} \text { high. }\end{array}$ \\
\hline \multirow[t]{3}{*}{ Vegetation } & Shrub Thickets & $\begin{array}{l}\text { Dominated by Betula nana shrubs and Salix spp. more } \\
\text { than } 25 \mathrm{~cm} \text { high, growing near water bodies, river } \\
\text { valleys and on hillsides. Forbs and graminoid plants are } \\
\text { abundant in the understory. }\end{array}$ \\
\hline & Wet Lowlands & $\begin{array}{l}\text { Occurs primarily in areas of flat topography with poor } \\
\text { drainage, often close to lakes and rivers where flooding } \\
\text { occurs. Characterized by a continuous layer of } \\
\text { Sphagnum mosses more than } 10 \mathrm{~cm} \text { thick, and } \\
\text { abundant graminoids with a few dwarf shrubs. }\end{array}$ \\
\hline & Mesic Tundra & $\begin{array}{l}\text { Characterized by tussocks of Eriophorum vaginatum } L \text {. } \\
\text { and other graminoids. Dwarf shrubs and lichens are } \\
\text { also abundant in these areas, and forbs occur at lower } \\
\text { abundance. A thick, sometimes discontinuous, moss } \\
\text { layer could also be found across hilltops, depending on } \\
\text { microrelief and drainage. }\end{array}$ \\
\hline
\end{tabular}


Table S2. Internal validation accuracies (\%) calculated with the validation points created from unchanged validation pixels using the CVA methodology and external validation accuracies (\%) calculated independently with high resolution imagery. Confidence intervals at $95 \%$ confidence levels

467

\begin{tabular}{|c|c|c|c|c|c|c|}
\hline \multirow{2}{*}{ Year } & \multicolumn{3}{|c|}{ Internal Validation } & \multicolumn{3}{|c|}{ External Validation } \\
\hline & UA & PA & $\mathrm{OA}$ & UA & OA & PA \\
\hline 2016 & $95.0( \pm 2.5)$ & $59.9( \pm 9.1)$ & $82.8( \pm 2.9)$ & $94.1( \pm 5.0)$ & $\begin{array}{c}70.9 \\
( \pm 15.7)\end{array}$ & $84.1( \pm 4.3)$ \\
\hline 2018 & $98.0( \pm 1.6)$ & $77.9( \pm 10.9)$ & $86.9( \pm 2.9)$ & $91.9( \pm 4.1)$ & $84.9( \pm 7.4)$ & $88.1( \pm 2.1)$ \\
\hline
\end{tabular}

468

469

* UA - Area-adjusted User's Accuracy; PA - Area-adjusted Producer's Accuracy; OA - Overall Accuracy 